\title{
FATIGUE PROPERTIES OF NODULAR CAST IRON AT LOW FREQUENCY CYCLIC LOADING
}

\begin{abstract}
Three melts of ferrite-pearlitic nodular cast iron with different charge composition were used for fatigue tests. Wöhler fatigue curves and fatigue strength were obtained, and microstructure and fracture surfaces were investigated. The aim of the paper is to determine the influence of charge composition on microstructure, mechanical and fatigue properties of synthetic nodular cast irons and their micromechanisms of failure. Fatigue tests were realised at low frequency sinusoidal cyclic push-pull loading (stress ratio $R=-1)$ at ambient temperature $\left(T=20 \pm 5^{\circ} \mathrm{C}\right)$. They were carried out with using the fatigue experimental machine Zwick/Roell Amsler $150 \mathrm{HFP} 5100$ at frequency $f \approx 120 \mathrm{~Hz}$. The results of fatigue tests at low frequency cyclic loading are compared with fatigue properties at high frequency cyclic loading.

Keywords: fatigue test, low frequency cyclic loading, nodular cast iron, steel scrap, silicon carbide
\end{abstract}

\section{Introduction}

Fatigue has been a predominating fracture mode of loadbearing machine members. Therefore, through the years its prevention has become a fundamental design criterion. Although fatigue has been studied extensively over many years and excellent reference books are now available, further study is needed because the knowledge base is partly obsolete and new materials and treatments are continuously being developed.

Fatigue testing is usually performed to estimate the relationship between the amplitude of stress and the number of cycles to failure for a particular material or component. Fatigue testing is also conducted to compare the fatigue properties of two or more materials or components. In either case the reliability of any decision based on the results of a fatigue testing program is directly related to the manner in which the experiments are designed and analysed [1].

Nodular cast iron is a group of cast structural materials with a wide application in engineering practice (especially in the automotive industry). It combines high tensile strength and plasticity with high fatigue strength. Nodular cast iron can be produced according to the classical or synthetic casting procedure (Fig. 1) which is more economical [2].

In recent years, the production of nodular cast iron has been from an economic point of view orientated to synthetic melts where a part of more expensive pig iron in a metal charge

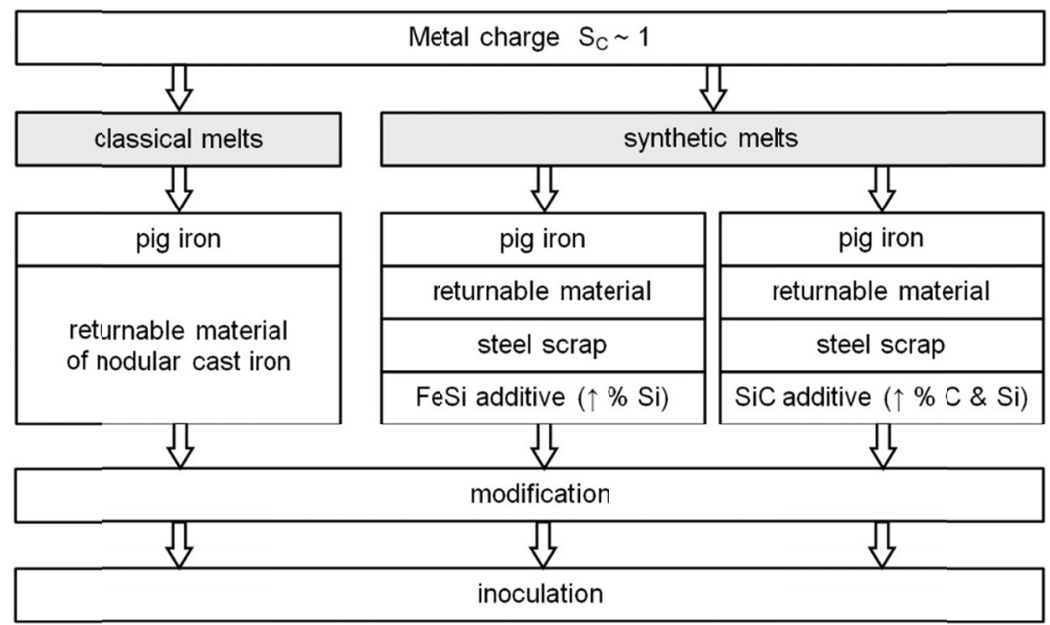

Fig. 1. Scheme of the production of nodular cast iron

\footnotetext{
* UNIVERSITY OF ŽILINA, FACULTY OF MECHANICAL ENGINEERING, DEPARTMENT OF MATERIAL ENGINEERING, UNIVERZITNÁ 8215/1, 010 26 ŽILINA, SLOVAKIA

\# Corresponding author: alan.vasko@fstroj.uniza.sk
} 
is substituted for cheaper steel scrap. The transition from the traditional use of pig iron (classical melts) to synthetic nodular cast iron prepared from steel scrap requires the regulation of chemical composition of melt. Steel scrap has low content of silicon therefore increasing of content of silicon to eutectic composition $\left(\mathrm{S}_{\mathrm{C}} \sim 1\right)$ is reached by using of ferrosilicon $(\mathrm{FeSi})$ or metallurgical silicon carbide ( $\mathrm{SiC}$ ) additive. Nowadays, there is the tendency to use metallurgical silicon carbide as a siliconizing as well as carburizing additive instead of ferrosilicon. SiC additive increases the count of crystallisation nuclei of graphite in the melt, consequently the count of graphitic nodules per unit of area is increased (the size of graphitic nodules is decreased) and at the same time the susceptibility to occurrence of carbide in the structure is decreased. A further influence of $\mathrm{SiC}$ additive is its ferritizing effect when the content of ferrite in the matrix is increased [3].

The technological foundry literature describes the addition of $\mathrm{SiC}$ to the cast iron melt frequently as having a special preinoculating effect $[4,5]$. This influence is well documented in the case of grey cast iron and has also been observed to some extent at laboratory as well as at industrial experiments in the case of nodular cast iron.

\section{Experimental material and methods}

The specimens from three melts of nodular cast iron were used for experiments. The resultant melts have approximately the same chemical composition but this was achieved by different charge composition (Table 1). The basic charge of individual melts was formed by different ratio of pig iron and steel scrap and by different additive for the regulation of chemical composition (carburizer and metallurgical silicon carbide or ferrosilicon). The content of these additives was chosen to achieve approximately the same resultant chemical composition of the melts (eutectic degree $S_{C} \approx 1.0$ ). For modification FeSiMg7 modifier was used and for inoculation FeSi75 inoculant was used (Table 2).

TABLE 1

Charge composition of experimental melts

\begin{tabular}{|c|c|c|c|c|}
\hline \hline $\begin{array}{c}\text { Melt } \\
\text { number }\end{array}$ & $\begin{array}{c}\text { Pig iron } \\
(\mathbf{\% )}\end{array}$ & $\begin{array}{c}\text { Steel scrap } \\
\mathbf{( \% )}\end{array}$ & Additive & $\begin{array}{c}\text { Modifier \& } \\
\text { inoculant }\end{array}$ \\
\hline 1 & 40 & 60 & carburizer + SiC90 & \multirow{2}{*}{ FeSiMg7 +} \\
FeSi75 \\
\hline 2 & 0 & 100 & carburizer + SiC90 & \\
\hline 3 & 40 & 60 & carburizer + FeSi75 & \\
\hline
\end{tabular}

Experimental bars (diameter $32 \mathrm{~mm}$ and length $350 \mathrm{~mm}$ ) were cast from all the melts and consequently experimental specimens for tensile test, impact bending test, hardness test and fatigue tests were made (Fig. 2).

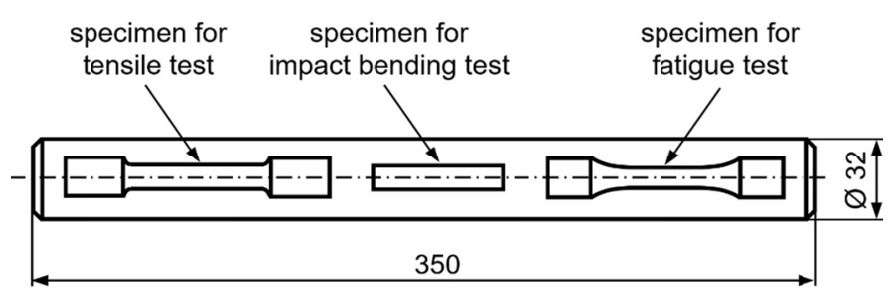

Fig. 2. Taking of specimens from experimental bars

The metallographic analysis of specimens from experimental melts was made by the light metallographic microscope Neophot 32. The specimens for metallographic analysis were taken out from the cast bars and prepared by usual metallographic procedure. The microstructure of specimens was evaluated according to STN EN ISO 945 (STN 42 0461) and by automatical image analysis (using NIS Elements software) [6-8]. The image analysis was used for the evaluation of content of ferrite in the matrix and count of graphitic nodules per unit of area.

The tensile test was made according to STN EN ISO 6892-1 by means of the testing equipment ZDM 30 with a loading range $F=0$ to $50 \mathrm{kN}$. The impact bending test was made according to STN EN ISO 148-1 by means of the Charpy hammer PSW 300 with a nominal energy of $300 \mathrm{~J}$. For tensile test and impact bending test, five specimens from each melt were used to determine the mechanical properties. The Brinell hardness test was made according to STN EN ISO 6506-1 by means of the testing equipment CV-3000 LDB with a hardmetal ball of diameter $D=10 \mathrm{~mm}$ forced into specimens under the load $F=29430 \mathrm{~N}$ (3000 kp) [9-11].

The fatigue tests were carried out according to STN 42 0362 at low frequency sinusoidal cyclic push-pull loading (stress ratio $R=-1$, frequency $f \approx 120 \mathrm{~Hz}$ ) at ambient temperature ( $T=20 \pm 5^{\circ} \mathrm{C}$ ) using the fatigue experimental machine Zwick/ Roell Amsler 150HFP 5100 (Fig. 3a,b). Specimens of circular cross-section were used for fatigue tests. Shape and parameters of the specimens for low frequency cyclic loading are shown in Fig. 3c. For fatigue tests, ten specimens from each melt were used to determine the fatigue characteristics [12-15].

The microfractographic analysis was made by the scanning electron microscope VEGA II LMU on fracture surfaces of the specimens fractured by fatigue tests $[16,17]$.

TABLE 2

Chemical composition of experimental melts

\begin{tabular}{|c|c|c|c|c|c|c|c|c|c|}
\hline \multirow{2}{*}{$\begin{array}{c}\text { Melt } \\
\text { number }\end{array}$} & \multicolumn{8}{|c|}{ Content of chemical elements (weight \%) } & \multirow{2}{*}{$S_{C}$} \\
\hline & $\mathbf{C}$ & $\mathrm{Si}$ & Mn & $\mathbf{P}$ & $\mathrm{S}$ & $\mathrm{Cr}$ & $\mathbf{C u}$ & Sn & \\
\hline 1 & 3,58 & 2,43 & 0,39 & 0,05 & 0,028 & 0,08 & 0,01 & 0,021 & 1,01 \\
\hline 2 & 3,70 & 2,84 & 0,17 & 0,03 & 0,037 & 0,09 & 0,01 & 0,024 & 1,09 \\
\hline 3 & 3,61 & 2,23 & 0,23 & 0,05 & 0,031 & 0,07 & 0,01 & 0,022 & 1,01 \\
\hline
\end{tabular}




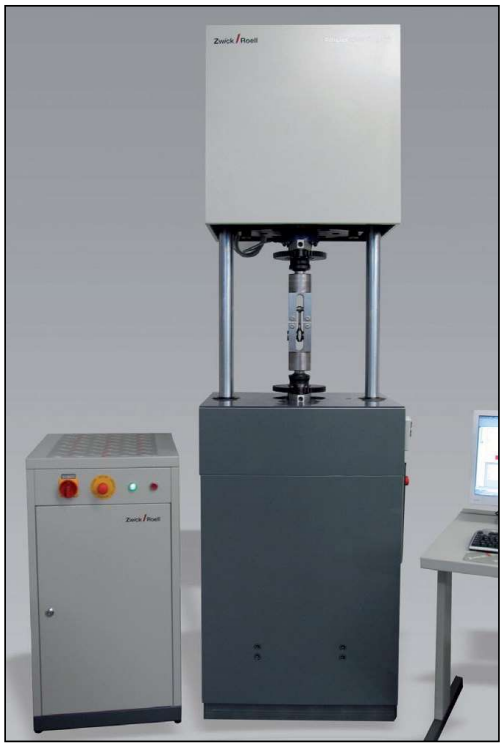

a) fatigue experimental machine Zwick/Roell Amsler 150HFP 5100

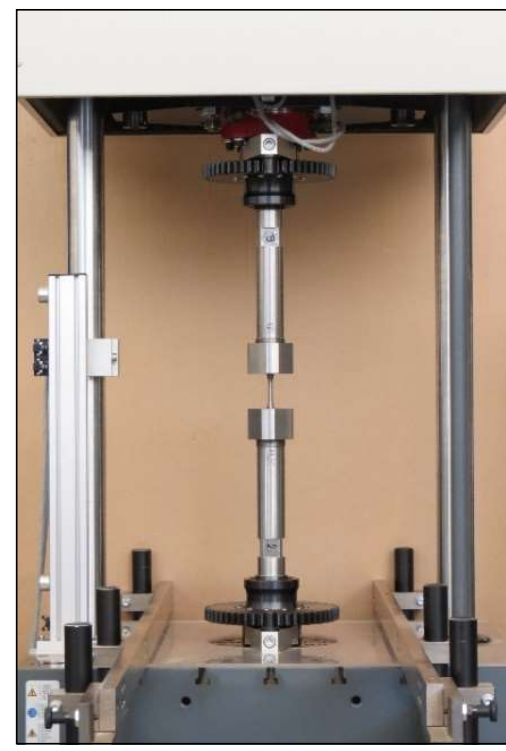

b) detail of fatigue testing

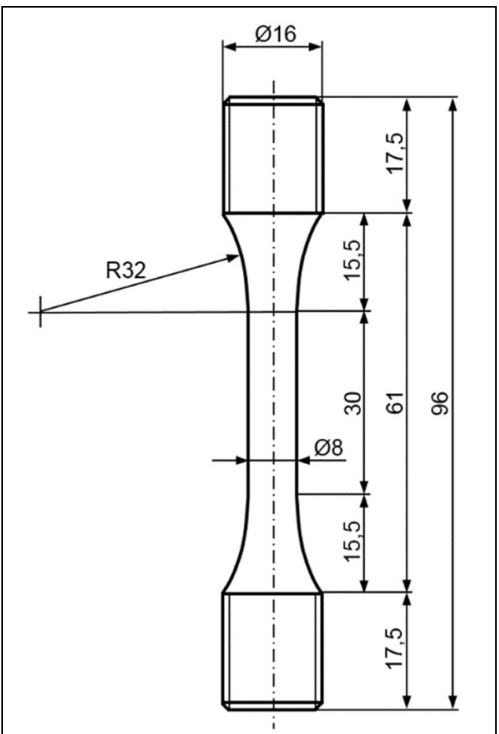

c) shape and parameters of the specimens

Fig. 3. Fatigue machine and specimen used for experiments

\section{Experimental results and discussion}

From a microstructural point of view, the specimens from all the melts are ferrite-pearlitic nodular cast irons (Fig. 4) with different content of ferrite and pearlite in the matrix, different size of graphite and count of graphitic nodules (Table 3). Different content of ferrite and pearlite in the matrix as well as different size of graphite and count of graphitic nodules in the individual specimens are caused by different ratio of pig iron and steel scrap in the charge and by different kind of additive for the regulation of the chemical composition ( $\mathrm{SiC}$ or $\mathrm{FeSi}$ ).

The results of evaluation of the microstructure of the specimens from the cast bars by STN EN ISO 945 (STN 42 0461) and by image analysis (content of ferrite and count of graphitic nodules) are presented in Table 3. The content of ferrite in the specimens from the melts with $\mathrm{SiC}$ additive is higher than in the specimens from the melts with FeSi additive. The highest content of ferrite was reached in the melt 2 created only by steel

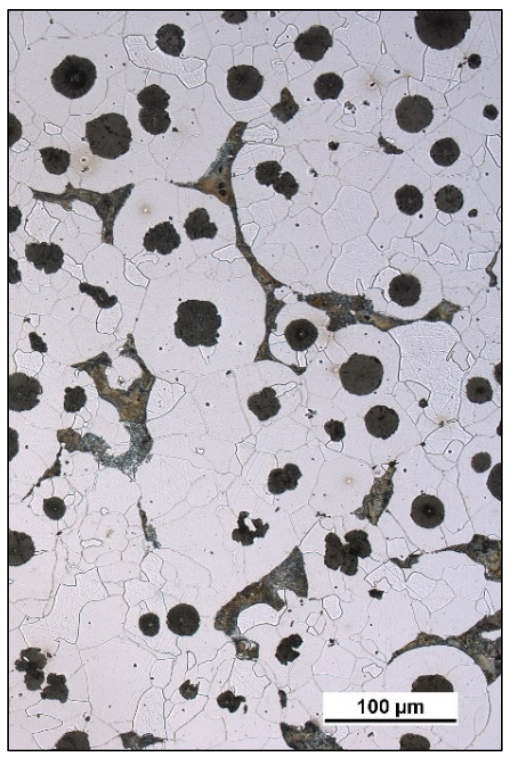

a) melt 1

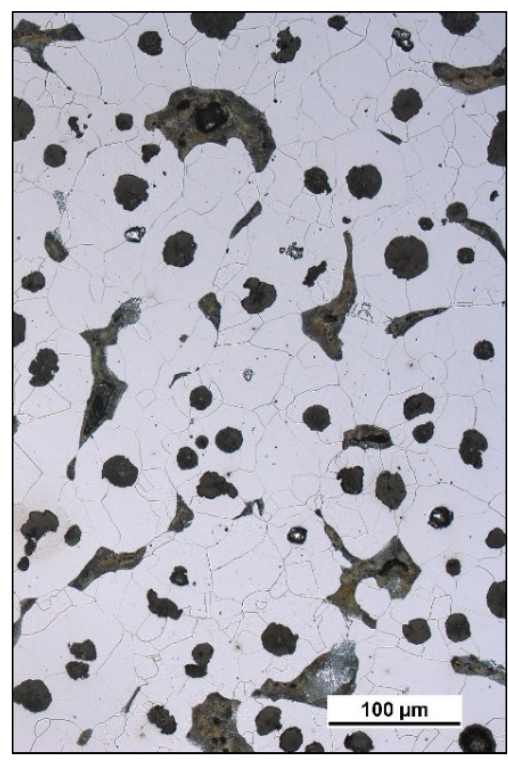

b) melt 2

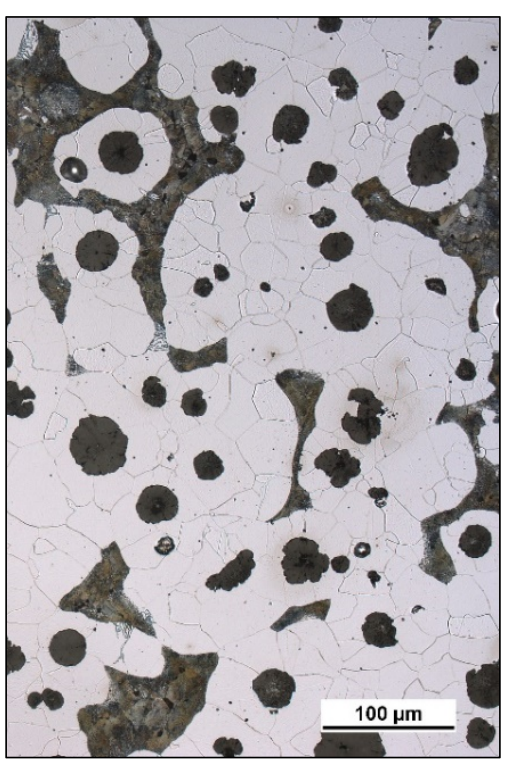

c) melt 3

Fig. 4. Microstructure of the specimens from cast bars, etched by $1 \%$ Nital 
scrap and $\mathrm{SiC}$ additive (approximately 78\%) and in the melt 1 created by $60 \%$ of steel scrap and $40 \%$ of pig iron with $\mathrm{SiC}$ additive (74\%). Graphite occurs only in a perfectly-nodular and imperfectly-nodular shape in all the specimens. The ratio of perfectly-nodular graphite in the specimens from the melts with $\mathrm{SiC}$ additive is higher than in the specimens from the melts with FeSi additive. The size of graphite is from 30 to $120 \mu \mathrm{m}$, but in all the specimens the size within $30-60 \mu$ m predominates. The size of graphite in the specimens from the melts with $\mathrm{SiC}$ additive is generally smaller than in the specimens from the melts with FeSi additive. The average count of graphitic nodules per unit of area in the specimens from the melts with $\mathrm{SiC}$ additive is higher than in the specimens from the melts with FeSi additive. The highest count of graphitic nodules is in the melt 1 created by $60 \%$ of steel scrap and $40 \%$ of pig iron with $\mathrm{SiC}$ additive (almost $200 \mathrm{~mm}^{-2}$ ).

TABLE 3

Results of evaluation of the microstructure

\begin{tabular}{|c|c|c|c|}
\hline \hline $\begin{array}{c}\text { Melt } \\
\text { number }\end{array}$ & $\begin{array}{c}\text { Microstructure } \\
\text { (according to } \\
\text { STN EN ISO 945) }\end{array}$ & $\begin{array}{c}\text { Content } \\
\text { of ferrite } \\
\text { (\%) }\end{array}$ & $\begin{array}{c}\text { Count of } \\
\text { graphitic } \\
\text { nodules }\left(\mathbf{m m}^{-2}\right)\end{array}$ \\
\hline 1 & $80 \% \mathrm{VI} 6+20 \% \mathrm{~V} 6-\mathrm{Fe} 94$ & 74.0 & 199.8 \\
\hline 2 & $70 \% \mathrm{VI} 5 / \underline{6}+30 \% \mathrm{~V} 6-\mathrm{Fe} 94$ & 78.0 & 179.8 \\
\hline 3 & $70 \% \mathrm{VI} 5 / \underline{6}+30 \% \mathrm{~V} 6-\mathrm{Fe} 80$ & 65.2 & 151.0 \\
\hline
\end{tabular}

The results of mechanical tests (tensile strength UTS, elongation EL, absorbed energy $\mathrm{K} 0$ and Brinell hardness $\mathrm{HBW}$ ) are given in Table 4. The specimens from the melts with $\mathrm{SiC}$ additive have better mechanical properties than the specimens from the melts with $\mathrm{FeSi}$ additive. It has connection with the microstructure of the specimens, especially with the character of matrix (content of ferrite and pearlite) and also with the size and count of graphitic nodules [18]. The best mechanical properties were reached in the melt 1 created by $60 \%$ of steel scrap and $40 \%$ of pig iron with $\mathrm{SiC}$ additive, which has the highest ratio of perfectly-nodular graphite, the smallest size of graphite and the highest count of graphitic nodules.

TABLE 4

Mechanical properties of the specimens

\begin{tabular}{|c|c|c|c|c|}
\hline \hline Melt number & UTS (MPa) & EL (\%) & K0 (J) & HBW 10/3000 \\
\hline 1 & 539.0 & 4.0 & 30.6 & 192.3 \\
\hline 2 & 515.7 & 3.7 & 17.2 & 182.3 \\
\hline 3 & 462.6 & 2.7 & 24.0 & 181.3 \\
\hline
\end{tabular}

For the fatigue tests, ten specimens from each melt were used to obtain Wöhler fatigue curves $\sigma_{a}=f(N)$ and determine fatigue strength $\sigma_{c}$ for $N=10^{7}$ cycles.

The results of fatigue tests (relationship between stress amplitude $\sigma_{a}$ and number of cycles to failure $N_{f}$ ) obtained at low frequency cyclic loading $(f \approx 120 \mathrm{~Hz})$ are shown in Fig. 5 . The number of cycles to failure increases with a decreasing stress amplitude.

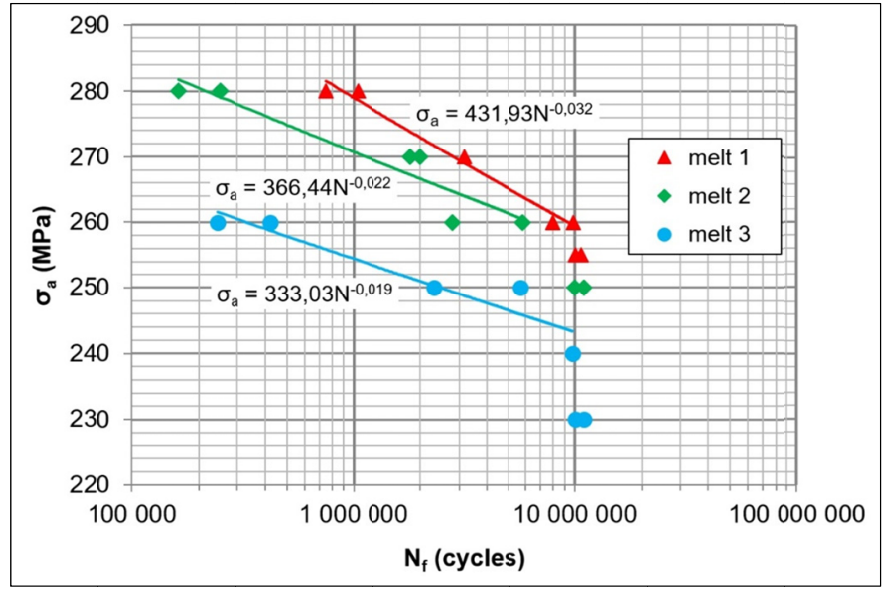

Fig. 5. Wöhler curves $\sigma_{a}=f(N)$ for low frequency cyclic loading $(f \approx 120 \mathrm{~Hz})$

The values of fatigue strength $\sigma_{\mathrm{c}}$ determined for $N=10^{7}$ cycles in comparison with tensile strength UTS are given in Table 5. The fatigue strength in analysed specimens of nodular cast iron increases with an increasing tensile strength. The fatigue strength in the specimens from the melts with $\mathrm{SiC}$ additive is higher than in the specimens from the melts with FeSi additive. The highest fatigue strength $(255 \mathrm{MPa})$ was reached in the melt 1 created by $60 \%$ of steel scrap and $40 \%$ of pig iron with SiC additive, which has the best mechanical properties.

TABLE 5

Comparison of tensile strength UTS and fatigue strength $\sigma_{c}$

\begin{tabular}{|c|c|c|}
\hline \hline Melt number & UTS (MPa) & $\boldsymbol{\sigma}_{c}$ (MPa) \\
\hline 1 & 539.0 & 255 \\
\hline 2 & 515.7 & 250 \\
\hline 3 & 462.6 & 230 \\
\hline
\end{tabular}

For comparison, the results of fatigue tests obtained at high frequency cyclic loading $(f \approx 20 \mathrm{kHz})$ are shown in Fig. 6 [19]. The results obtained at low frequency cyclic loading are in a good agreement with the results obtained at high frequency

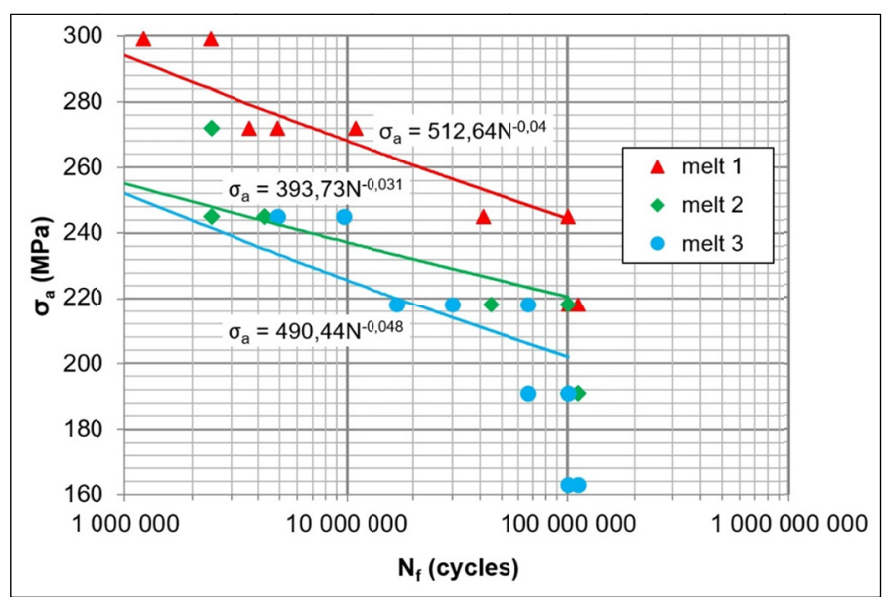

Fig. 6. Wöhler curves $\sigma_{a}=f(N)$ for high frequency cyclic loading $(f \approx 20 \mathrm{kHz})$ 
cyclic loading. In both cases, the fatigue strength $\sigma_{c}$ increases with an increasing tensile strength UTS.

The fracture surfaces of analysed specimens after fatigue failure do not show any remarkable differences; they are characteristic of mixed mode of fracture.

The fracture surface of the specimen from the melt 1 after low frequency cyclic loading (stress amplitude $\sigma_{a}=270 \mathrm{MPa}$, $N_{f}=3.2 \times 10^{6}$ cycles) is shown in Fig. 7. The fatigue fracture was initiated by casting defect (Fig. 7a). The fatigue fracture is characteristic of intercrystalline fatigue failure of ferrite around graphitic nodules and transcrystalline fatigue failure of ferrite and pearlite in the rest of the area (Fig. 7b). The final rupture is characteristic of transcrystalline cleavage of ferrite and pearlite with river drawing on facets (Fig. 7c) and transcrystalline ductile failure of ferrite with dimple morphology (Fig. 7d).

No significant differences were observed by the comparison of fracture surfaces of the specimens from the analysed melts. The fatigue failure has a mixed character of fracture (intercrystalline and transcrystalline fatigue failure) in all the specimens; the intercrystalline fatigue failure predominates near graphitic nodules and the transcrystalline fatigue failure predominates in the rest of the area.

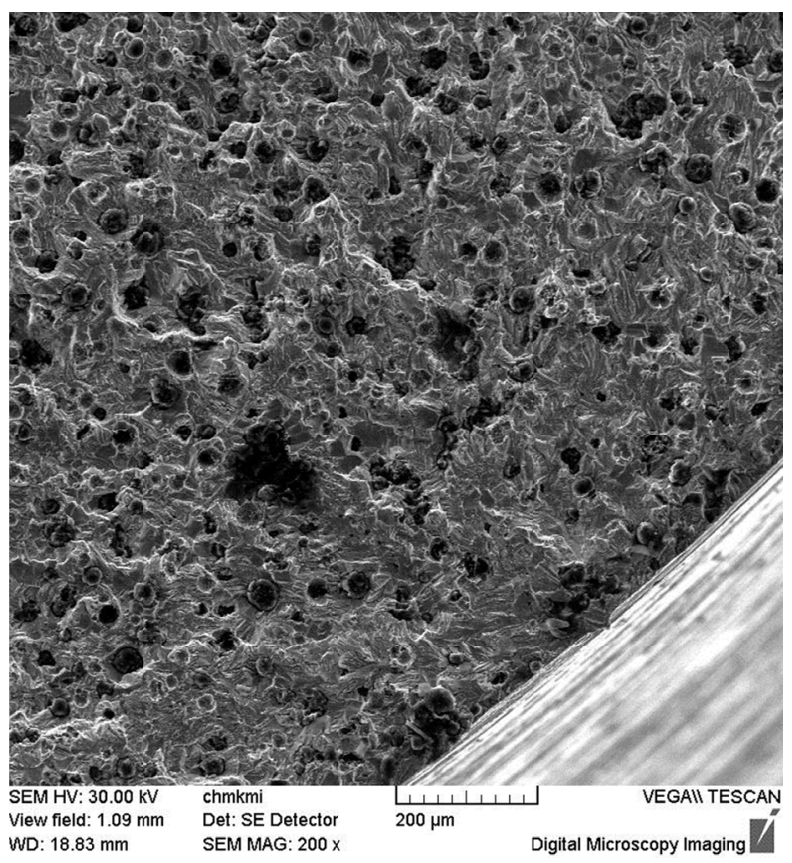

a) initiation of fatigue failure

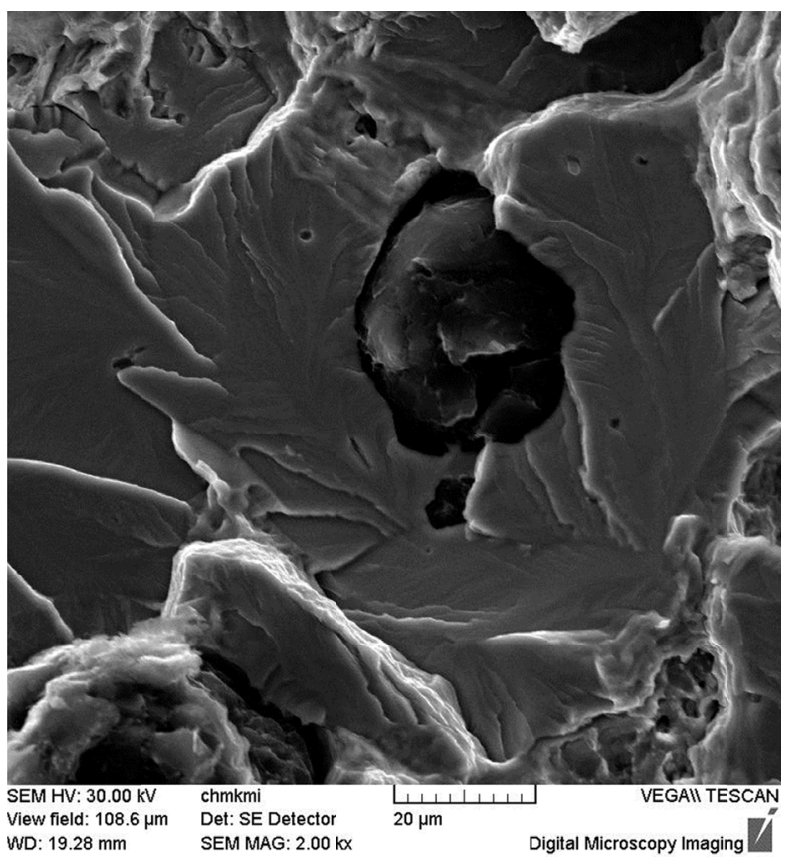

c) transcrystalline cleavage

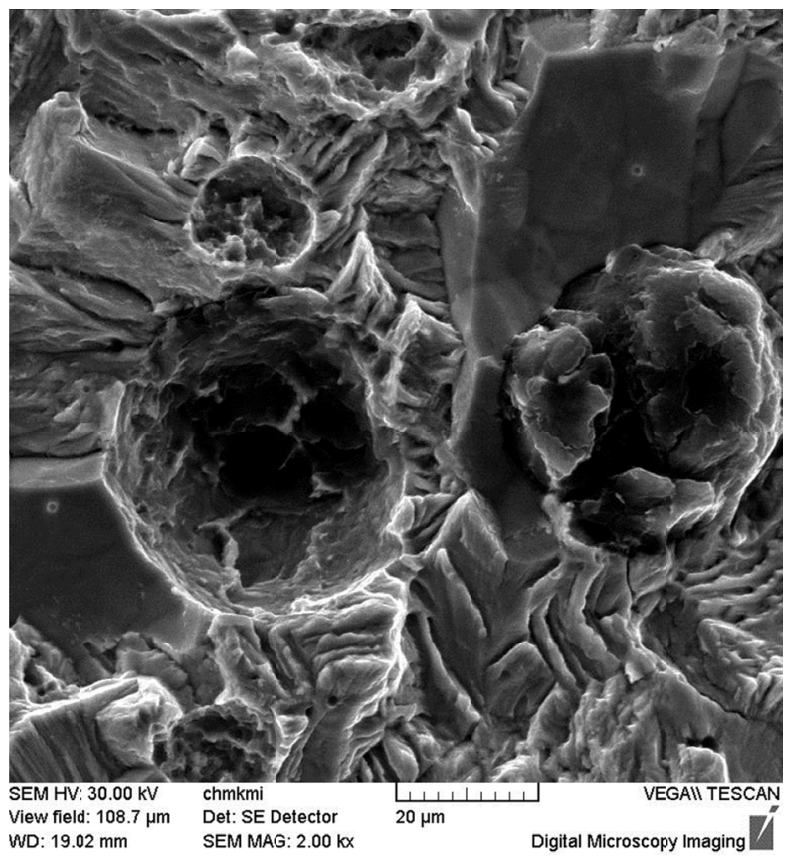

b) trans- and intercrystalline fatigue failure

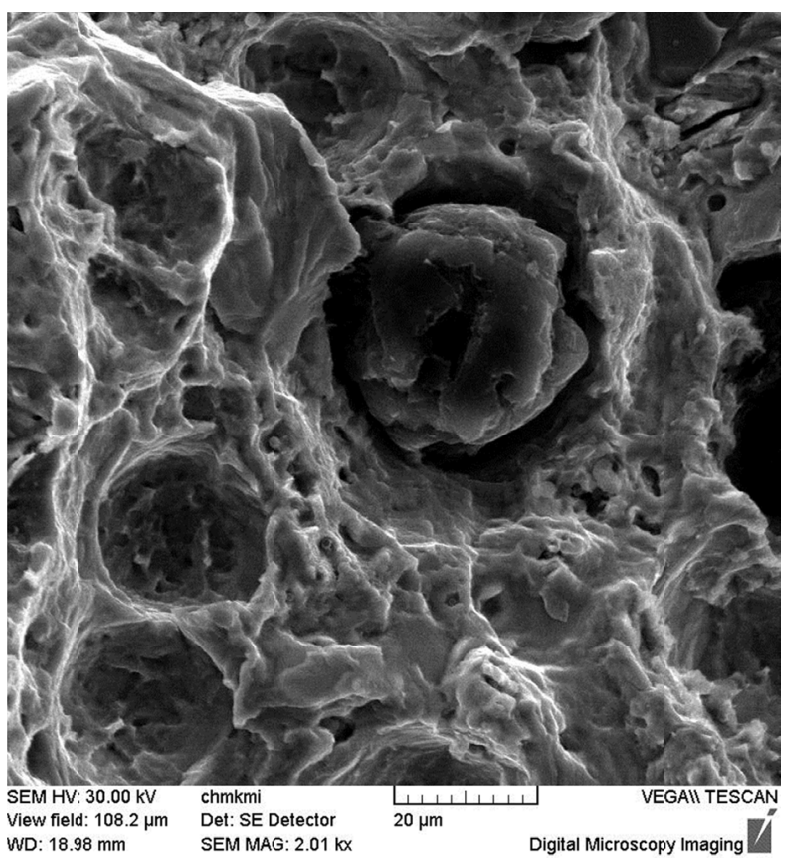

d) transcrystalline ductile failure

Fig. 7. Failure micromechanisms of the specimen from the melt $1\left(f=120 \mathrm{~Hz}, \sigma_{a}=270 \mathrm{MPa}, N_{f}=3.2 \times 10^{6}\right.$ cycles), SEM 


\section{Conclusions}

The results of the experiments show that the charge composition influences the microstructure, mechanical as well as fatigue properties of nodular cast iron. The substitution of a part of pig iron for steel scrap in the charge of nodular cast iron has a considerable economic contribution. For the regulation of chemical composition of the melt it is advantageous to use the metallurgical $\mathrm{SiC}$ additive which has been used in this work as an alternative additive instead of FeSi in melts with a different ratio of steel scrap in the charge.

The experimental results can be summarized to the following points:

- the $\mathrm{SiC}$ additive positively influences the microstructure, it means the content of ferrite in the matrix is increased, the size of graphite is decreased and the average count of graphitic nodules per unit of area is increased; consequently the mechanical and fatigue properties of nodular cast iron are improved;

- the mechanical properties (tensile strength, elongation, impact toughness and hardness) are improved with increasing ratio of perfectly-nodular graphite, decreasing size of graphite, increasing count of graphitic nodules and increasing content of ferrite;

- the best mechanical and fatigue properties from the analysed specimens were reached in the specimens from the melt 1 created by $60 \%$ of steel scrap and $40 \%$ of pig iron in the basic charge with $\mathrm{SiC}$ additive;

- micromechanisms of failure of structural components depends especially on the content of ferrite in the matrix and its purity, which has a connection with the charge composition; higher ratio of transcrystalline ductile failure is characteristic for higher content of ferrite in the matrix.

\section{Acknowledgement}

This work has been supported by the Scientific Grant Agency of Ministry of Education, Science, Research and Sport of Slovak Republic, grant project VEGA No. 1/0533/15 and by the Culture and Educational Grant Agency of Ministry of Education, Science, Research and Sport of Slovak Republic, grant project KEGA No. 044ŽU-4/2014.

\section{REFERENCES}

[1] O. Bokůvka, G. Nicoletto, M. Guagliano, L. Kunz, P. Palček, F. Nový, M. Chalupová, Fatigue of materials at low and high frequency loading, Žilina 2014.

[2] R. Konečná, M. Kokavec, G. Nicoletto, Procedia Engineering 10, 2538 (2011).

[3] T. Benecke, S. Venkateswaran, W.D. Schubert, B. Lux, Foundryman 87, 355 (1994).

[4] K.W. Copi, Y.S. Lerner, N.S. Laukhin, Modern Casting 4, 29 (2003).

[5] W.H. Zhang, J. Ding, F.R. Nie, Zhuzao/ Foundry 3, 279 (2009).

[6] P. Skočovský, A. Vaško, Quantitative evaluation of structure of cast irons, Žilina 2007. (in Slovak).

[7] P. Skočovský, O. Bokůvka, R. Konečná, E. Tillová, Materialscience, Žilina 2014. (in Slovak).

[8] R. Konečná, S. Fintová, Methods of structure study, Žilina 2014. (in Slovak).

[9] A. Vaško, P. Skočovský, Properties and using of metal materials, Žilina 2014. (in Slovak).

[10] S. Borkowski, R. Ulewicz, Laboratory of materialscience for engineers, Częstochowa 2009. (in Polish).

[11] P. Kopas, M. Vaško, M. Handrik, Applied Mechanics and Materials 474, 285 (2014)

[12] S. Věchet, J. Kohout, O. Bokůvka, Fatigue properties of nodular cast iron, Žilina 2001. (in Czech).

[13] J. Belan, Metalurgija/ Metallurgy 1, 59 (2015).

[14] F. Nový, P. Kopas, O. Bokůvka, A. Savin, Manufacturing Technology 2, 406 (2016)

[15] R. Ulewicz, F. Nový, J. Selejdak, Advanced Materials Research 874, 43 (2014).

[16] P. Palček, M. Chalupová, in: Summer school of fatigue of materials 2006, 95, Žilina (2006). (in Slovak).

[17] G. Hütter, L. Zybell, M. Kuna, Engineering Fracture Mechanics, 144, 118 (2015).

[18] A. Burbelko, D. Gurgul, E. Guzik, W. Kapturkiewicz, Archives of metallurgy and materials 3, 2379 (2015).

[19] A. Vaško, J. Belan, L. Kuchariková, E. Tillová, Metalurgija/ Metallurgy 1-2, 25 (2017). 